\title{
THE ECONOMIC SITUATION OF THE FOOD INDUSTRY IN EU COUNTRIES
}

\author{
Piotr Borawski ${ }^{1}$, phd habilitated; Aneta Beldycka-Borawska ${ }^{2}, \mathrm{msc}^{\text {, }}$ \\ Ireneusz Zuchowski ${ }^{3}$, phd; James W Dunn ${ }^{4}$, professor \\ ${ }_{1,2}$ University of Warmia and Mazury in Olsztyn, Poland; ${ }^{3}$ Higher School of Agribusiness in Lomza, Poland; \\ ${ }^{4}$ Pennsylvania State University, the USA
}

\begin{abstract}
The aim of this paper is to present economic situation of food industry in Poland on the background of the EU countries in the years 2011-2015. The authors used tabular and descriptive methods to present the changes in the economic situation of food industry enterprises and analysed turnover, value added, number of employees and number of companies. We calculated the median, standard deviation, coefficient of variation, skewedness and kurtosis to analyse the changes in turnover and value added of food industry in EU countries. The survey proves that the food industry is developing well. Consolidation has been noticed, which means that the food companies are growing while their number is decreasing. The turnover of the food industry increased in the years 2011-2015 in almost in all EU countries, excluding Finland (-3.5\%) and Sweden (-5.7\%). The value added of the food industry decreased in the years 2011-2015 only in the Czech Republic $(-6.9 \%)$, the Netherlands $(-2.1 \%)$, Spain $(-3.5 \%)$. The number of food industry companies decreased in the years 20112015 only in Austria (-0.7\%), Belgium (-9.4\%), Denmark (-0.2\%), Finland (-2.8\%), Germany (-2.5\%) and Spain $(-13.3 \%)$.
\end{abstract}

Key words: food industry, enterprises, EU.

JEL code: Q12, Q11

\section{Introduction}

Food is the basic productthat fulfils the needs of consumers. Food needs can be supported by products that can be bought on the market or by products produced on your own farm. Food can be bought and consumed in different places, for example by buying products from producers or stores for preparation of food at home (Stanko, Hamulczuk 2017).

The food industry is the most important industry within the EU and the world. It is responsible for 1.048 billion EUR production in the EU. This sector employs 4.2 million people, which accounts for $15.5 \%$ of total employment in the production sector (Data \& Trends..., 2014). Another factor stressing the importance of food industry is its $13 \%$ share of all production companies in the EU among 286.000 companies (Juchniewicz, Lukiewska, 2015). The food industry and agriculture are important sectors not only because of high employment, but also because of preventing food crises. As Timmer (2010) claims, "the food crisis is usually set off by a shock to either supply or demand for food and often involves a sudden spike in food prices". The food crisis can be described as the period of high and volatile food prices. The globalisation of food markets has an impact on food prices (Hamulczuk 2017).

The sector involves not only food enterprises, but also the agricultural sector is involved in production and distribution of food. This sector takes part in the world's Global Value Chain (Borawski et al., 2017).

The development of the food industry on the farm level in the EU market is restricted by the CAP. Generally, the CAP reforms were focused on providing substantial payments to farmers. Moreover, the CAP insists on food quality, environmental maintenance, and farm diversification on the second hand (Barnes et al., 2016). Other reforms in 2015 were focused on separation of farm payments from production and adding "greening requirements". The budget of the CAP increased while the funding available at the national and individual farm levels decreased (European Commission, 2013). 
Today agribusiness enterprises are dependent on various factors such as production and distribution costs, technical development, and ways of management. The food industry is characterized by a high degree of division of labour and plays an important role in the economy (Hajderllari, Karantininis, 2012). As far as the level of competitiveness is concerned, the food enterprises in Poland are at lower level compared to more developed countries of the EU. The competitiveness depends on factors controlled by agriculture and the agri-food sector. The second group of factors are external factors, mainly: climate, rural policy, and tariffs (Wieliczko, 2014). The evaluation of efficiency of the agri-food sector depends on international trade indicators and strategic management. Especially important are the integration processes of small enterprises with big trade nets among farms (Kociszewski, Szwacka-Mokrzycka, 2011). The food industry is one of the most important parts of the economy because it is responsible for the nutrition of people and is an exporter of agricultural goods. Nowadays, the agri-food enterprises try to find new export possibilities, create new investments, and increase human capital (Firlej, Zmija, 2014). The agrifood enterprises try to develop a competitive advantage by fulfilment of the requirements of customers, ensuring high quality products by proper transport and storage conditions and optimization of product flows in agri-food chains (Baran, 2012; Klepacki, Rokicki, 2011).

The aim of this paper is to present the economic situation of the food industry in Poland on the background of the EU countries in the years 2011-2016. To develop the problem of economic situation of food industry the authors wanted to answer following questions:

1) What is the turnover of food industry in Poland?

2) How does the turnover and value added change regionally?

3 ) Is the number of employees and number of companies increasing?

4) What is the coefficient of variation, kurtosis and skewedness of turnover and value added of food industry?

We used tabular and descriptive methods to present the changes in the economic situation of the food industry. We calculated the median, standard deviation, coefficient of variation, skewedness, and kurtosis to analyze the changes in turnover and value added of the food industry in EU countries.

\section{Research results and discussion}

The development of the food industry is important because it uses agricultural products and creates demand for agricultural products. Thus, it is very important to allow common development of agriculture and the food industry. Cheap agricultural products delivered to the nutritious industry have an impact on processed products, which can be exported at lower prices. The situation on the food market in the EU changed in 2004 after new Member States joined the EU, including Poland. Countries such as Poland had advantages in such products as beef meat, poultry meat, meat and fish products, flour and starch products, and other (Braja, Sawicka, 2017).

One of the tools which is used in evaluation of food industry development is an industrial production index (so called industrial output index or industrial volume index). It measures the changes in the price adjusted-output of industry (Data \& Trends..., 2017). Total manufacturing in the EU countries increased from the first quarter 2016 to first quarter 2017 by $1.9 \%$. The food and drink industry's production index also increased in 2016-2017 (0.9\%). The data prove that the 
food and drink industry in the EU countries is developing slowly, but steadily (Hajderllari, Karantininis, 2012).

Table 1 presents food and drink data of the EU countries in the years 2011-2015. The turnover decreased in Sweden $(-5.7 \%)$ and Finland $(-3.5 \%)$. It increased in other countries and did not change in Slovenia. The biggest turnover rates in 2015 were found in France (179.9 billion EUR), Germany (168.6 billion EUR), Italy (132 billion EUR), and the United Kingdom (131.6 billion EUR). The smallest turnover in 2015 was found in Estonia (1.8 billion EUR), Latvia (1.7 billion EUR), Slovenia (2.2 billion EUR), Lithuania (4.0 billion EUR), and Slovakia (4.0 billion EUR). The biggest increase of turnover in the years 2011-2015 was noticed in Austria (+80.2\%), the United Kingdom $(+50.2)$, Hungary $(+38.5)$ and Greece $(+29.1)$.

Turnover industry data in the years 2011-2015

Table 1

\begin{tabular}{|c|c|c|c|c|c|c|c|c|c|}
\hline \multirow{2}{*}{ Country } & \multicolumn{2}{|c|}{$\begin{array}{c}\text { Turnover } \\
\text { (EUR billion) }\end{array}$} & \multirow[b]{2}{*}{ 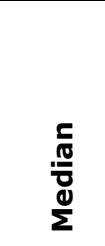 } & \multirow{2}{*}{ 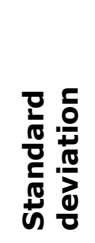 } & \multirow{2}{*}{ 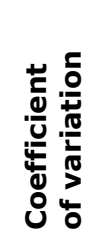 } & \multirow{2}{*}{ 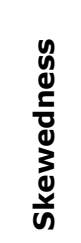 } & \multirow[b]{2}{*}{$\begin{array}{l}\frac{n}{n} \\
\stackrel{0}{t} \\
\underline{J} \\
\underline{5}\end{array}$} & \multirow{2}{*}{ 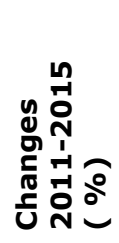 } & \multirow{2}{*}{ 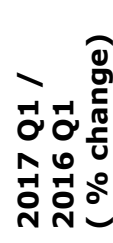 } \\
\hline & 2011 & 2015 & & & & & & & \\
\hline Austria & 12.6 & 22.7 & 20.3 & 4.02 & 20.8 & -1.1 & -0.3 & +80.2 & 0.4 \\
\hline Belgium & 44.5 & 48.6 & 48.0 & 1.6 & 3.5 & -1.3 & 0.0 & +9.2 & 7.0 \\
\hline Bulgaria & 4.7 & 5.2 & 4.9 & 0.2 & 4.2 & 0.7 & -0.8 & +10.6 & 0.2 \\
\hline Cyprus & 1.5 & - & 1.5 & 0.0 & 0.0 & - & - & - & - \\
\hline Croatia & - & 5.3 & 5.2 & 0.1 & 1.4 & -2.1 & -0.5 & - & \\
\hline $\begin{array}{l}\text { Czech } \\
\text { Republic }\end{array}$ & 11.3 & 13.3 & 11.6 & 1.3 & 10.6 & 0.4 & -1.7 & +17.7 & 6.2 \\
\hline Denmark & 25.4 & 25.4 & 24.6 & 0.6 & 2.3 & -0.4 & -0.8 & 0.0 & 3.3 \\
\hline Estonia & 1.5 & 1.8 & 1.8 & 0.2 & 9.6 & -0.3 & -1.4 & +20.0 & 3.7 \\
\hline Finland & 11.3 & 10.9 & 11.2 & 0.2 & 1.6 & -0.4 & -1.6 & -3.5 & -1.0 \\
\hline France & 157.2 & 179.9 & 160 & 12.9 & 7.6 & 0.4 & -1.7 & +14.4 & 2.8 \\
\hline Germany & 163.3 & 168.6 & 169.3 & 4.4 & 2.6 & -0.3 & -0.9 & +3.2 & 2.9 \\
\hline Greece & 11 & 14.2 & 14.2 & 1.8 & 13.8 & -0.4 & -1.8 & +29.1 & 2.8 \\
\hline Hungary & 8.3 & 11.5 & 11.2 & 1.6 & 15.5 & -0.4 & -1.8 & +38.5 & 2.8 \\
\hline Ireland & 22.0 & 27.1 & 26.4 & 2.6 & 10.3 & -0.4 & -1.8 & +23.2 & 4.3 \\
\hline Italy & 127.0 & 132 & 132 & 2.2 & 1.7 & -1.0 & -0.6 & +3.9 & 2.5 \\
\hline Latvia & 1.6 & 1.7 & 1.6 & 0.2 & 11.7 & -0.8 & -0.5 & +6.2 & 4.5 \\
\hline Lithuania & 3.6 & 4.0 & 4.0 & 0.3 & 6.9 & -0.1 & -1.6 & +11.1 & 7.8 \\
\hline Netherlands & 59.2 & 70.0 & 66.6 & 4.5 & 6.9 & -0.4 & -1.4 & +18.2 & 4.5 \\
\hline Poland & 49.7 & 55.6 & 49.7 & 3.2 & 6.1 & 0.4 & -1.8 & +11.9 & 9.8 \\
\hline Portugal & 14.5 & 15.3 & 14.9 & 0.3 & 2.3 & 0.3 & -1.2 & +5.5 & 8.2 \\
\hline Romania & 10.5 & 12.0 & 11.1 & 0.6 & 5.2 & 0.6 & -0.7 & +14.3 & 6.7 \\
\hline Slovakia & 3.7 & 4.0 & 3.8 & 0.3 & 8.1 & 1.1 & -0.3 & +8.1 & - \\
\hline Slovenia & 2.2 & 2.2 & 2.2 & 0.1 & 4.2 & -0.8 & -0.9 & 0.0 & - \\
\hline Spain & 83.8 & 104.2 & 91.5 & 7.4 & 8.0 & 0.6 & -0.5 & +24.3 & 5.2 \\
\hline Sweden & 19.2 & 18.1 & 19.2 & 0.7 & 3.4 & -0.4 & -1.6 & -5.7 & 4.4 \\
\hline $\begin{array}{l}\text { United } \\
\text { Kingdom }\end{array}$ & 87.6 & 131.6 & 114 & 16.2 & 14.3 & -0.7 & -0.5 & +50.2 & - \\
\hline
\end{tabular}

Source: authors' calculations based on FoodDrinkEurope National Federations, 2011-2015 
The increase of turnover and production of food industry in EU-15 was driven by new members joining EU. It was the effect of increasing exports of agri-food products and increased internal demand (Beba, Poczta, 2014).

The index of industrial turnover measures the development of turnover (sales) in the European industry (it is influenced by changes in prices of the traded industrial goods and by changes of the volumes of goods traded) (Data\&Trends..., 2017). The turnover index in total manufacturing in the first quarters of 2016-2017 increased by $6.7 \%$. The turnover index of food and drink industry in the first quarters of 2016-2017 also increased b4.3\%.

Table 1 presents the descriptive statistics for turnover in selected EU countries. The coefficient of variation informs about changes. The highest were observed in Austria (20.3\%), Hungary $(15.5 \%)$ and the United Kingdom (14.3\%). The lowest coefficients of variation in the years 20112015 were found in Finland (1.6 \%) and Italy (1.7\%). Cyprus noted no changes in turnover.

The kurtosis, which is an asymmetry measures, has negative values in most countries of the EU what is, indicating that they were different in the analyzed period in relation to the mean. Only Belgium achieved positive kurtosis, which suggests the similarity to the mean.

The skewedness which is also a asymmetry measure, has negative values in most countries of the EU. Other counties such as Bulgaria, the Czech Republic, France, Poland, Portugal, Romania, Slovakia and Spain noted positive skewedness which suggests similar values to the mean.

The food and drink industry turnover in the first quarters of 2016-2017 increased in almost all countries. It only decreased in Finland. The biggest increase of turnover in the EU was observed in Poland (9.8\%), Portugal (8.2\%), and Lithuania (7.8\%).

Another characteristic of the food industry is profitability. It means that the company wants to achieve positive results out of activity (Szymanska, 2017). It is measured by the relationship to referenced economic value. The author measured the profitability on the pig market. She found that the return on equity in Polish pig meat enterprises was $12.45 \%$ in $2008,17.49 \%$ in 2010 and in $2012-6.95 \%$. The economic downturn on the pig market caused the decrease of return on equity. It means that the food market in Poland and other countries is very sensitive to crises.

The value added decreased in the Czech Republic and the Netherlands (tab. 2). It did not change in Hungary, Portugal and Slovenia. The biggest value added in 2015 was found in France (45 billion EUR), Germany (36.7 billion EUR), the United Kingdom (38.9 billion EUR), and Italy (24.2 billion EUR). The smallest value added of the food and drink industry in 2015 was found in Estonia and Latvia ( 0.4 billion EUR), Slovenia ( 0.5 billion EUR) and Slovakia ( 0.8 billion EUR). The largest values were in the largest economies. The biggest increase of value added in the years 2011-2015 was found in Germany (219.1\%), Greece $(100.0 \%)$, and the United Kingdom $(64.1 \%)$. The decrease of value added in the years 2011-2015 was found in the Czech Republic ($6,9)$, the Netherlands $(-21,0)$, and Spain $(-3.5 \%)$.

After introduction to the EU the new countries in 2004 the pace of the development of food industry increased. In 2008 during the world financial crises the development of the food industry decreased (Beba, Poczta, 2014).

Table 2 presents the descriptive statistics for values added in EU countries. The coefficient of variation informs about changes in value added. The highest were observed in Croatia $(82.4 \%)$, France (44.6\%) and Germany (34.9\%). The lowest coefficient of variation in the years 2011-2015 were found in Italy $(9,2 \%)$ and France $(12,1 \%)$. 
The kurtosis, which is the asymmetry measure, has negative values in most countries of the EU that is, indicating that they were different in the analyzed period in relation to the mean. Only Croatia, Estonia, Germany and Slovakia achieved positive kurtosis, which suggests the similarity to the mean.

The skewedness, which is also a asymmetry measure, has negative values in the Czech Republic, Estonia, France, Germany and other countries, which indicates that they were different in the analyzed period in relation to the mean. Other counties such as Australia, Belgium, Bulgaria, Croatia, Denmark, Finland, Greece, Hungary, Italy, Latvia, and Lithuania noted positive skewedness which suggests similar values to the mean.

Value added of food industry data in the years 2011-2015

Table 2

\begin{tabular}{|c|c|c|c|c|c|c|c|c|}
\hline \multirow{2}{*}{ Country } & \multicolumn{2}{|c|}{$\begin{array}{l}\text { Value added } \\
\text { (EUR billion) }\end{array}$} & \multirow[b]{2}{*}{$\frac{5}{\frac{0}{0}}$} & \multirow{2}{*}{ 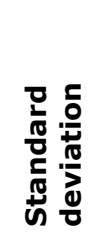 } & \multirow{2}{*}{ 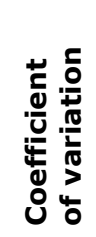 } & \multirow{2}{*}{ 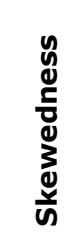 } & \multirow{2}{*}{$\begin{array}{l}\frac{n}{n} \\
0 \\
\frac{t}{3} \\
x\end{array}$} & \multirow{2}{*}{ 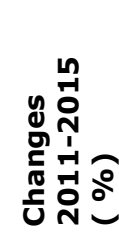 } \\
\hline & 2011 & 2015 & & & & & & \\
\hline Austria & 4.7 & 5.5 & 5.1 & 0.3 & 6.2 & 0.4 & -0.9 & +17.0 \\
\hline Belgium & 6.7 & 8.1 & 7.4 & 0.6 & 7.9 & 0.2 & -1.4 & +20.9 \\
\hline Bulgaria & 0.8 & 1.0 & 0.8 & 8.9 & 0.1 & 0.8 & -0.9 & +25.0 \\
\hline Cyprus & 0.4 & - & 0.4 & 0.0 & 0.0 & n.a & n.a. & - \\
\hline Croatia & - & 1.2 & 1.2 & 1.6 & 82.4 & 1.5 & 0.3 & - \\
\hline Czech Republic & 2.9 & 2.7 & 2.4 & 0.4 & 15.8 & -0.2 & -1.1 & -6.9 \\
\hline Denmark & 3.2 & 4.5 & 3.2 & 0.7 & 20.5 & 0.4 & -1.8 & +40.6 \\
\hline Estonia & 0.3 & 0.4 & 0.4 & 0.9 & 12.3 & -.5 & 0.2 & +33.3 \\
\hline Finland & 2.5 & 2.6 & 2.6 & 0.0 & 3.2 & 0.3 & -1.2 & +4.0 \\
\hline France & 29.3 & 45.0 & 29.3 & 12.9 & 44.6 & -0.2 & -1.0 & +53.6 \\
\hline Germany & 11.5 & 36.7 & 34.2 & 10.5 & 34.9 & -1.5 & 0.2 & +219.1 \\
\hline Greece & 1.4 & 2.8 & 1.5 & 0.6 & 33.1 & 0.9 & -0.6 & +100.0 \\
\hline Hungary & 2.0 & 2.0 & 2.0 & 0.2 & 10.2 & 1.2 & 0.0 & 0.0 \\
\hline Ireland & 6.0 & - & 7.1 & 0.6 & 8.4 & -0.7 & -0.4 & \\
\hline Italy & 24.2 & 24.2 & 24.2 & 1.7 & 7.2 & 0.5 & -0.4 & 0.0 \\
\hline Latvia & 0.3 & 0.4 & 0,3 & 0.1 & 16.1 & 0.4 & -1.8 & +33.3 \\
\hline Lithuania & 0.6 & 0.8 & 0.6 & 0.1 & 13.6 & 0.8 & -0.9 & +33.3 \\
\hline Netherlands & 14.3 & 11.3 & 13.3 & 1.8 & 13.9 & -0.1 & -1.6 & -21.0 \\
\hline Poland & 8.9 & 9.9 & 9.9 & 0.7 & 0.1 & 0.0 & -1.5 & +11.2 \\
\hline Portugal & 2.9 & 2.9 & 2.9 & 0.1 & 0.1 & -0.6 & -1.4 & -0.0 \\
\hline Romania & 2.2 & - & 1.9 & 0.2 & 8.1 & 0.4 & -1.8 & - \\
\hline Slovakia & 0.7 & 0.8 & 0.7 & 0.0 & 6.2 & 1.5 & 0.3 & +14.3 \\
\hline Slovenia & 0.5 & 0.5 & 0.5 & 0.1 & 11.9 & -0.4 & -1.8 & 0.0 \\
\hline Spain & 20.0 & 19.3 & 26.8 & 4.5 & 18.3 & -0.4 & -1.8 & -3.5 \\
\hline Sweden & 4.4 & 4.5 & 0.5 & 0.1 & 2.9 & -0.4 & -1.4 & +2.3 \\
\hline $\begin{array}{l}\text { United } \\
\text { Kingdom }\end{array}$ & 23.7 & 38.9 & 31 & 5.5 & 17.7 & -0.0 & -0.8 & +64.1 \\
\hline
\end{tabular}

Source: author's calculations based on FoodDrinkEurope National Federations, 2011-2015

The food industry is a very important source of employing people. This is very visible in Poland, where the food industry employs more than 417 thousand people and occupies $2.7 \%$ in the country's economy. In comparison, the employment in agriculture in Poland in 2015 was 2333.4 thousand people, which occupies $16.2 \%$ of the country's economy. The employment in 
agriculture in Poland was six times higher than in the food industry; however, it can be described as permanent. The development of the economy causes a lower contribution of agriculture in gross domestic products. This can be explained by the lower income elasticity of demand on food products in comparison to other goods (Pawlewicz, Brodzinski, 2017).

The employment in the food industry in the EU countries changed in the years 2011-2015. The number of employees decreased in the years 2011-2015 in the following countries: Belgium, Bulgaria, France, Latvia, the Netherlands, Portugal, Romania, Slovakia, Spain and Sweden (tab. 3). It increased in the remaining countries of the EU. The data exhibit the consolidation processes in the food industry in the EU countries. In Poland, all of the macroeconomic factors of the food industry increased. The biggest numbers of employees in 2015 in the food and drink industry were found in France (427.2 thousand), Germany ( 569.2 thousand) and Italy (427 thousands). The smallest number of employees in 2015 was found in Estonia (15.4 thousand), Slovenia (16.5) and Latvia (23.7). The biggest increase in the number of employees in the years 2011-2015 was found in Austria (43.6 \%), Greece (34.1\%) and Estonia (18.5\%). The biggest decrease in the number of employees in the food and drink industry in the years 2011-2015 was found in France $(-14.6 \%)$ and Spain (-21.7\%).

The labour input measures the number of persons employed in the total manufacturing industry vs. the food and drink industry in the EU, seasonally adjusted (Data \& Trends..., 2017). The employment index of total manufacturing increased in the first quarters of 2016-2017 (1.4\%). The employment index of the food and drink industry also increased in the first quarters of 2016-2017 $(2.0 \%)$.

The labour resources in the food industry were measured by Juchniewicz (2017), who analysed the food producer's competitiveness gap in Poland on the European Union market. She found that the largest share of employed persons in food production of all the employed in the EU-28 in 2013 was recorded in Germany (20.3\%), France (14.0\%), Italy $(9.7 \%)$, Poland $(9.5 \%)$, the UK $(9.2 \%)$ and Spain $(7.7 \%)$. She also measured the productivity of labour of food producers. The index was the highest in Belgium, the Netherlands, France, the UK and Germany. In Romania, the productivity was the smallest.

The competitiveness of the food industry in the EU market is determined by consolidation processes. This issue can be seen in almost all marketing chains from rural producers to suppliers of production means and retail trade. These processes are not stable and they caused different competitiveness. The strongest is the retail trade because of big shops' contribution in food trade (Stanko, Hamulczuk, 2016).

The employment in food industry in Poland and EU countries was the effect of integration and restructuring processes. The changes in labour of the food industry are similar to those in whole economy. The increased condition of the economy, increased demand on EU markets and exports of agricultural products caused the increase of employment in many countries of EU (Beba, Poczta, 2014).

Another characteristic of the food and drink industry is the number of companies (tab. 3). The largest number of companies in 2015 was found in Spain (26.016), Poland (14.534) and Portugal (10.096). The smallest number of companies in 2015 was found in Slovakia (278), Estonia (575) and Ireland (1583). The biggest increase in the number of companies in the years 2011-2015 was 
found in Italy $(793.9 \%)$, France $(472.9 \%)$ and Slovenia $(86.0 \%)$. The biggest decrease in the years 2011-2015 was found in Spain (-13.3\%), Belgium (-9.4\%) and Finland (-2.8\%).

Number of employees and number of companies in the years 2011-2015

Table 3

\begin{tabular}{|c|c|c|c|c|c|c|c|}
\hline \multirow[t]{2}{*}{ Country } & \multicolumn{2}{|c|}{$\begin{array}{c}\text { Number of } \\
\text { employees } \\
(1.000)\end{array}$} & \multirow{2}{*}{$\begin{array}{c}\text { Changes } \\
\text { 2011-2015 } \\
(\%)\end{array}$} & \multirow{2}{*}{$\begin{array}{c}2017 \text { Q1 / } \\
2016 \text { Q1 } \\
\text { ( \% } \\
\text { change) }\end{array}$} & \multicolumn{2}{|c|}{$\begin{array}{l}\text { Number of } \\
\text { companies }\end{array}$} & \multirow{2}{*}{$\begin{array}{c}\text { Changes } \\
\text { 2011-2015 } \\
(\%)\end{array}$} \\
\hline & 2011 & 2015 & & & 2011 & 2015 & \\
\hline Austria & 58 & 83.3 & +43.6 & 2.7 & 3.921 & 3.893 & -0.7 \\
\hline Belgium & 89 & 88.5 & -0.6 & 1.8 & 4.912 & 4.452 & -9.4 \\
\hline Bulgaria & 99 & 95.6 & -3.4 & 1.3 & 5.612 & 6.182 & +10.1 \\
\hline Cyprus & 13 & - & - & - & 863 & - & - \\
\hline Croatia & - & 61.0 & - & -4.2 & - & 3.256 & - \\
\hline Czech Republic & 105 & 115.4 & +9.9 & 2.1 & 8.360 & 9.157 & +9.5 \\
\hline Denmark & 55 & 61.6 & +12.0 & 0.3 & 1.610 & 1.607 & -0.2 \\
\hline Estonia & 13 & 15.4 & +18.5 & 0.6 & 422 & 575 & +36.2 \\
\hline Finland & 33 & 37.6 & +13.9 & -13.5 & 1.900 & 1.846 & -2.8 \\
\hline France & 500 & 427.2 & -14.6 & 2.4 & 10.000 & 57.290 & +472.9 \\
\hline Germany & 550 & 569.2 & +3.5 & 2.7 & 5.960 & 5.812 & -2.5 \\
\hline Greece & 65 & 87.2 & +34.1 & - & 1.180 & 1.225 & +3.8 \\
\hline Hungary & 97 & 106.6 & +9.9 & - & 6.556 & 6.812 & +3.9 \\
\hline Ireland & 43 & 47.3 & $+10,0$ & 9.7 & 689 & 1.583 & +129.7 \\
\hline Italy & 408 & 427.0 & +4.6 & - & 6.300 & 56.315 & +793.9 \\
\hline Latvia & 25 & 23.7 & -5.2 & -3.0 & 788 & 1,120 & +42.1 \\
\hline Lithuania & 42 & 44.1 & +5.0 & -4.4 & 1.205 & 1.609 & +33.5 \\
\hline Netherlands & 131 & 128.6 & -1.8 & - & 4.385 & 6.065 & +38.3 \\
\hline Poland & 403 & 417.5 & +3.6 & 3.5 & 13.708 & 14.534 & +6.0 \\
\hline Portugal & 110 & 107.5 & -2.3 & 2.6 & 10.513 & 10.996 & +4.6 \\
\hline Romania & 186 & 180.8 & -2.8 & 0.9 & 8.239 & 8.826 & +7.1 \\
\hline Slovakia & 30 & 29.3 & -2.3 & - & 218 & 278 & +27.5 \\
\hline Slovenia & 16 & 16.5 & +3.1 & - & 1.214 & 2.258 & +86.0 \\
\hline Spain & 446 & 349.2 & -21.7 & 6.4 & 30.000 & 26.016 & -13.3 \\
\hline Sweden & 56 & 50.5 & -9.8 & - & 3.400 & 4.240 & +27.7 \\
\hline $\begin{array}{l}\text { United } \\
\text { Kingdom }\end{array}$ & 370 & 418.2 & 13.0 & -0.3 & 6.500 & 6.620 & +1.8 \\
\hline
\end{tabular}

Source: author's calculations based on FoodDrinkEurope National Federations, 2011-2015

Poland has faced many changes in food industry subjects, particularly on milk market. The number of wholesaler suppliers decreased from 311.1 (thousand) in 2005 to 130.3 (thousand) in 2014 (decrease $44.3 \%$ ). Poland had the biggest number of wholesaler suppliers in the EU. The smallest number of wholesaler suppliers in the EU countries was observed in 2015 in Cyprus (204) and Estonia (640). Big economies in milk production, particularly Germany had 72.6 thousand wholesaler suppliers in 2016, France - 66.7 thousand suppliers in 2015 and Austria 33.3 thousand suppliers (Analizy i prognozy rynkowe, 2015). Moreover, the number of direct suppliers of milk decreased from 76 thousand in 2005 to 10.8 thousand in 2014 (decrease $(85.8 \%)$. However, the average wholesaler supply of milk increased from 27 tonnes per supplier to 73 tonnes in 2014 (increase $270.4 \%$ ). The average number of dairies decreased from 181 companies in 2014 to 165 in 2017 (8.8 decrease). These results demonstrate the changes on the Polish milk market (Trajer, Krzyzanowska, 2015). 
The biggest decrease of food industry enterprises is observed in small and medium-sized enterprises. The biggest increase is observed in large enterprises. These processes are the effect of concentration in food industry in EU. The level of concentration measured by the increase of numbers of large enterprises is bigger than the decrease of small enterprises (Tereszczuk, 2013).

The development of food industry in EU countries is linked with the outlays on research and innovations. The biggest has been observed in nutritious articles, beverages and cigarettes. In Poland for example most of outlays on research and development was directed to professional experience of employees and marketing of new products. The biggest increase of outlays was observed in knowledge purchase for external sources and programs (Zmija, 2015).

\section{Conclusions, proposals, recommendations}

1) The food industry is a very important part of the economy in the EU countries. The survey proved this development. The EU is a big producer of food and a very important player on the world markets. The EU is the largest exporter and importer of food products within the world. The enlargement of the EU in 2004 has led to the effect of creativity trade and internal trade (Juchniewicz, 2017).

2) The food sector is one of the fastest growing EU market sectors. However, this sector is very sensitive to financial crises. This issue can be confirmed by sudden changes in all variables analysed in this paper.

3) The turnover data prove the development of food industry in Europe. The turnover increased in almost all countries of the EU. It has decreased only in Sweden (-5.7\%) and Finland $(-3.5 \%)$. The biggest producers of food products in the EU measured by turnover in 2015 were France (179.9 billion EUR), Germany (168.6 billion EUR), Italy (132 billion EUR) and the United Kingdom (131.6 billion EUR).

4) Another characteristic describing the food industry is the value added. It is the result of turnover development in the countries. The research proved that the biggest value added in 2015 was found in France ( 45 billion EUR), Germany ( 36.7 billion EUR), the United Kingdom (38.9 billion EUR) and Italy (24.2 billion EUR). The biggest food producers of the EU are managing the market. The smallest countries and food producers are mainly importers. The smallest value added of the food and drink industry in 2015 was found in Estonia and Latvia ( 0.4 billion EUR), Slovenia ( 0.5 billion EUR), and Slovakia ( 0.8 billion EUR).

5) The employment data prove the development of food industry in the EU, which is characterized by consolidation processes and the changes of human resources by technical resources. The number of employees decreased in the years 2011-2015 in many countries, for example Belgium, Bulgaria, France, Latvia, the Netherlands, Portugal, Romania, Slovakia, Spain, and Sweden.

6) The number of companies also changed in the analysed period. The main producers of food with the biggest number of companies in 2015 on the one hand were Spain (26.016), Poland (14.534) and Portugal (10.096). On the other hand, the smallest number of companies in 2015 was found in Slovakia (278), Estonia (575), and Ireland (1583).

7) The coefficient of variation informs us about changes in turnover and value added of the food industry in EU countries. The biggest and positive changes of turnover were observed in Austria 
(20.3\%), Hungary (15.5\%) and United Kingdom (14.3\%). The biggest and positive changes in value added were observed in Croatia (82.4\%), France (44.6 \%) and Germany (34.9\%).

\section{Bibliography}

1. Analizy i prognozy rynkowe. Rynek mleka 2016 (Milk market 2016). Biuro Analiz i Programowania ARR. Informacja o sytuacji na rynku rolno-zywnosciowym z elementami tendencji rozwojowej 7/2016. (Information on the situation on the agri-food market with elements of the development trend7/2016).

2. Baran J. (2012). Skala dzialania a rozwiązania w zakresie magazynowania i transportu w przedsiebiorstwach przetworstwa mlaka (The scale of operations of dairy enterprises and their solutions in storage and transport). Logistyka 2, 343-352.

3. Beba P., Poczta W. (2014). Rozwoj i rola polskiego przemyslu spozywczego w warunkach akcesji do Unii Europejskiej (Development and the role of the Polish food industry in terms of accession to the European Union). Polityki Europejskie, Finanse i Marketing 11(60), p. 7-18.

4. Barnes, A., Sutherland, L. A., Toma, L., Matthews, K. (2016). The Effect of the Common Agricultural Policy Reforms on Intentions towards Food Production: Evidence from Livestock Farmers. Land Use Policy 50, 548558.

5. Borawski P., Beldycka-Borawska, A., Dunn, J. W., (2017). Industry in Poland. Proceedings of the 2016 International Conference ,"Economic Science for Rural Development" No 46, Jelgava, LLUESAF, 27-28 April 2017, p. 199-204.

6. Braja M., Sawicka J., (2017). Competitive Advantages of Polish Food Producers on the European Union Market in the Past-accession Period. Acta Sci. Pol. Oeconomia 16(2), 13-22.

7. Data \&Trend of the European Food and Drink Industry 2013-2014. FoodDrinkEurope, May 2014, available at: http://www.fooddrinkeurope.eu.

8. Data \&Trend of the European Food and Drink Industry 2013-2015. FoodDrinkEurope, May 2017, available at: http://www.fooddrinkeurope.eu.

9. European Commission (2013). Overview of CAP Reform 2014-2020. Agricultural Policy Perspectives. Brief No 5/ December 2013.

10. Firlej K., Zmija D., (2014). Knowledge Transfer and Diffusion of Innovation as a Source of Competitiveness of Food Industry Enterprises in Poland, Krakow, Wydawnictwo UEK i Fundacja UEK.

11. Hajderllari, L. Karantininis, K. (2012). The Structural Changes of the Food Industry in the European Union. FOI Working Paper 8, p. 1-15.

12. Hamulczuk M. (2017). Global Food Crises Symptoms, Implications, Causes. Journal of Agribusiness and Rural Development 3(45), 553-562.

13. Juchniewicz, M. (2017). Food Producer's Competitiveness Gap in Poland on the European Union Market. Acta Sci. Pol. Oeconomia 16(2), 65-75.

14. Juchniewicz, M., Lukiewska, K. (2015). Competitive Position of the Food Industry of the European Union on the Global Market. Acta Scientiarum Polonorum Oeconomia 14(3), p. 63-72.

15. Klepacki B., Rokicki T. (2011). Logistyka w przedsiebiorstwach przetworstwa owocow i warzyw (logistics in fruits and vegetables processing enterprises). Logistyka 3.

16. Kociszewski, M., Szwacka-Mokrzycka, J. (2011). Uwarunkowania rozwoju przemyslu spozywczego po przystapieniu Polski do UE (Conditions for Development of the Food Industry After the Polish Accession to the EU). Zeszyty Naukowe SGGW w Warszawie. Problemy Rolnictwa Swiatowego 11(26), 2. P. 67-76.

17. Pawlewicz A., Brodzinski Z. (2017). Zmiany potencjalu wytworczego w sektorze rolno-spozywczym w Polsce (Changes in production potential in agri-food sector in Poland). Roczniki Naukowe SERiA, tom XIX, zeszyt 2, 188-193.

18. Szymanska, E. (2017). Determinants of Profitability of Enterprises of Meat Industry in Poland. Acta Sci. Pol. Oeconomia 16(3), 83-91.

19. Stanko S., Hamulczuk M. (2016). Uwarunkowania zmian cen żywności - wprowadzenia (Conditioning of food changes - introduction) (in:) Hamulczuk M. (ed.) Ceny żywnosci w Polsce i ich determinanty (Food prices in Poland and their determinants). Instytut Ekonomiki Rolnictwa i Gospodarki Żywnościowej-PIB w Warszawie.

20. Tereszczuk M. (2013). Porownawcza ocena rozwoju przemuslu spozywczego w Polsce na tle innych krajow Unii Europejskiej (Comparative evaluation of the development of the food industry in Poland on the background of other countries of the European Union). Roczniki Naukowe SERiA 15(3), p. 361-366.

21. Timmer, C. P. (2010). Preventing Food Crises Using a Food Policy Approach. J. Nutr., 140, 2245-2285.

22. Trajer M., Krzyzanowska K., (2015). Tendencje zmian na rynku mleka i mozliwosci wspolpracy rolnikow w grupach producentow (Trends in changes on milk market and possibilities of cooperation of farmers in producer groups). Roczniki Naukowe SERiA 16(4), 328-334.

23. Wieliczko, B. (2014). Konkurencyjnosc sektora rolno-spozywczego UE w swietle wynikow handlu zagranicznego wybranych panstw (Competitiveness of the EU agri-food sector In the light of foreign trade balance of chosen countries). Zeszyty Naukowe SGGW w Warszawie. Problemy Rolnictwa Swiatowego $14(29), 2$, p. 226-237. 
Proceedings of the 2018 International Conference "ECONOMIC SCIENCE FOR RURAL DEVELOPMENT" No 49

Jelgava, LLU ESAF, 911 May 2018, pp. 222-231

DOI 10.22616/ESRD.2018.139

24.Zmija D. (2015). Wiedza jako czynnik rozowju przedsiębiorstw przemyslu spozywczego w Polsce

(Knowledge as a factor of the development of food industry companies in Poland). Roczniki Naukowe SERiA 17(4), p. 383-388. 